What causes ice ages?

\title{
触发和驱动第四纪冰期的机制是什么?
}

鹿化显 ${ }^{(12) *}$, 王班 ${ }^{(1)}$

(1) 南京大学地理与海洋科学学院, 南京 210023 ;

(2) 中国科学院青藏高原地球科学卓越创新中心, 北京 100101

* 联系人, E-mail: huayulu@nju.edu.cn

2015-11-17 收稿, 2016-02-16 修回, 2016-02-17 接受, 2016-03-25 网络版发表

国家自然科学基金(41321062, 41472138)资助

摘要晚新生代地球环境演化的重要事件包括冰期气候和人类起源等，其中，冰期及其旋回问题受到广泛关注， 但迄今没有被广泛接受的理论解释. 地球构造活动诱发的地表风化强度和大洋环流变化, 改变了大气 $\mathrm{CO}_{2}$ 含量和 地表热量传输过程, 其与地球运动轨道变化调制的太阳辐射量变化周期, 包括地球轨道偏心率、黄赤夹角和岁差 等, 共同驱动了第四纪大冰期降临及旋回变化. 其中, 太阳辐射量变化起主导作用. 在包括海陆配置、大气 $\mathrm{CO}_{2}$ 、 洋流变化、岩石风化等达到临界点的背景下, 太阳辐射量变化驱动着第四纪冰期气候旋回变化. 在晚上新世, 由于 地表化学风化加强、深海沉积埋藏碳增多, 使得大气中 $\mathrm{CO}_{2}$ 含量减少, 温室气体效应减弱; 加上高纬地区接受太阳 辐射量降到临界值，高纬地区冰川发育并形成强大的反馈机制，北半球冰期来临并在之后发生了中更新世冰期气 候转型. 在上新世-更新世的古气候变化中, 存在 400, 100, 41 和 $23 \mathrm{ka}$ 等周期, 这是太阳辐射量变化驱动的结果; 其中, 大气 $\mathrm{CO}_{2}$ 和冰冻圈反馈起到重要的放大作用. 近 200 年以来, 人类急剧向大气中排放 $\mathrm{CO}_{2}$ 气体, 增强了温室 气体效应, 可能改变冰期气候的趋向.

关键词冰期, 太阳辐射量, 大气 $\mathrm{CO}_{2}$ 含量, 大洋传送带, 轨道时间尺度

The important of the paper (Emiliani, 1955) was not in the particular results it presented, but in the way it opened an entirely new field of investigation with immense opportunities for learning about climate change. (这篇论文(Emiliani, 1955)的重要性不在于它 的结果, 而在于它开辟了一个从多个渠道研究气候变 化的全新领域.)

W. H. Berger, 2002. 483

第四纪是以冰期气候为主导的地球环境新阶段. 冰期气候的形成, 至少需要温度足够低、丰沛的水汽 两个条件. 其中, 地球接受太阳辐射量变化 ${ }^{[1]}$ 、大气 $\mathrm{CO}_{2}$ 含量变化 ${ }^{[2]}$ 、大洋温盐环流传送带关闭或运行 ${ }^{[3]}$ 、 赤道太平洋东西温度差异 ${ }^{[4]}$ 、大洋海水分层 ${ }^{[5]}$ 、地球
构造活动特别是陆地生长和高原隆升 ${ }^{[6]}$ 等, 都可能影 响到高纬地区的温度变化和水汽来源, 引发冰期气 候. 冰期气候的形成和发展，不是单一的地球外部或 者内部因素决定的，应该是多种因素综合作用的结 果. 当然，在不同的时间尺度上，这些关键因素的作 用可能发生变化. 迄今, 关于冰期气候的形成原因, 有多种假说，争议也很大. 在构造时间尺度，地表 (包括海洋表层, 下同)环境比如构造活动引起的大气 $\mathrm{CO}_{2}$ 含量减少、大洋环流变化等, 使大气温度降低并 形成反馈机制，地球进入冰期气候. 在渐新世以前, 也就是在 34 Ma以前的古近纪, 地球两极并无冰盖, 地球处于温室(温暖)气候期. 在 $2.7 \mathrm{Ma}$, 北半球的 冰盖急剧发展 ${ }^{[7]}$, 并在 1.0和 $0.5 \mathrm{Ma}$ 分别发生了中 
更新世和中布容气候转型, 体现在以 41 ka为主的周 期转变为 $100 \mathrm{ka}$ 的周期 ${ }^{[8]}$, 以及间冰期温度增高、大 气 $\mathrm{CO}_{2}$ 增多的特点 ${ }^{[9,10]}$. 同时, 第四纪气候变化表现 为显著的冰期-间冰期旋回特征. 那么, 引发和驱动 冰期气候的原因是什么?

\section{1 冰期气候的发现、特点及其影响}

在1837年, 美籍科学家Louis Agassiz等认为, 在 欧洲阿尔卑斯地区发现的岩石摩擦痕、混杂碎屑堆积 等, 是冰川沉积的产物, 表明地球经历过寒冷的冰期 气候. 其后, Emiliani ${ }^{[11]}$, Shackleton和Opdyke ${ }^{[12]}$ 研究 发现, 深海沉积物中浮游有孔虫的稳定氧同位素 ${ }^{18} \mathrm{O} /{ }^{16} \mathrm{O}$ 在万年时间尺度上, 存在周期性变化, 是地 表温度的记录, 并把深海沉积物有孔虫 ${ }^{18} \mathrm{O} /{ }^{16} \mathrm{O}$ 的变 化解释为陆地冰量和海洋温度综合作用的结果, 陆 地冰量变化可能起决定性作用. 因此, 可利用深海沉 积物 ${ }^{18} \mathrm{O} /{ }^{16} \mathrm{O}$ 变化重建地球气候变化过程, 揭示冰期间冰期气候旋回的特征和规律.

图1显示, 在距今 2.7 Ma, 北半球高纬地区冰川 急剧扩张, 深海氧同位素快速变重, 表明了北半球大 冰期的来临 ${ }^{[5,17]}$. 与此同时, 中国的黄土堆积广泛发 育、亚洲植被转型、非洲的古人类起源, 地球气候进 人一个新阶段 ${ }^{[18,19]}$. $\sim 2.7 \mathrm{Ma}$ 以来, 在北半球高纬地 区冰川广泛发育的背景下, 地球气候开始了剧烈的 万年时间尺度的旋回变化, 并且, 这些冷暖旋回变化 的温差平均可达 $5^{\circ} \mathrm{C}$, 在北半球和南半球的高纬地区, 甚至可以达到 $15^{\circ} \mathrm{C}^{[2,20]}$. 在古气候旋回变化中(图 1), 存在显著的 $100, \sim 41$ 和 $23 \mathrm{ka}$ 的周期, 其中 $~ 41$ 和 $\sim 23 \mathrm{ka}$ 的气候周期较为稳定, 而 $100 \mathrm{ka}$ 周期在最近 $\sim 1.2 \mathrm{Ma}$ 显著增强, 指示了冰期气候的转型特征 ${ }^{[8,21]}$. 在新生代更长的时间尺度, 还存在着 $400 \mathrm{ka}$ 的周期, 被称为“地球的心跳”, [22], 而 400 ka周期在 1.2 Ma以 来减弱, 与 100 ka周期增强形成对照, 可能是冰量 增多调制气候变化的结果. 与冰期气候旋回的变化 对应, 在 $2.7 \mathrm{Ma}$ 以来, 北半球接受太阳辐射量 ${ }^{[14]}$ 、大 气 $\mathrm{CO}_{2}$ 含量 ${ }^{[15]}$ 、大洋环流(包括北大西洋深层环流 $(\mathrm{NADW})$ 、大西洋经向反转流(AMOC) 和绕南极中层 水 $(\mathrm{AAIW})^{[5]}$ 、、南半球粉尘量 ${ }^{[16]}$ 、中国的黄土-古土 壤 ${ }^{[23]}$ 、亚洲植被和沙漠 ${ }^{[23]}$ 等, 都经历了多旋回的周期 变化(图1). 可见, 地球冰期-间冰期气候发展和旋回 变化, 既是对内外部强迫的响应, 也控制着地球的自 然地理环境.

\section{2 第四纪冰期气候的成因}

\section{1 第四纪冰期气候成因认识的发展和分歧}

关于第四纪冰期气候的起源，可分为构造时间 尺度(百万年级, Ma) 和轨道时间尺度(万年级, $10 \mathrm{ka}$ ) 来讨论. 在 $~ 5$ 到 $3.6 \mathrm{Ma}$, 地球处于暖期, 地表温度 高于现在 $\sim 3^{\circ} \mathrm{C}$, 海面升高10 20 m, 温盐环流加强, 南极冰盖有少量的减小、北半球有浮冰和小冰川出 现, 大气的 $\mathrm{CO}_{2}$ 含量可能高于工业革命前的 $30 \%^{[24,25]}$. 在 2.7 Ma以后, 地球进入冰期气候, 北半球高纬地 区冰川急剧扩张, 地表温度降低, (北半球)高纬地区 海洋表面和深层水温度降低、海水分层增强、温跃层 变浅，有显著的冰期-间冰期旋回和稳定的 100, 41 和 $23 \mathrm{ka}$ 的周期, 伴随着动物的长距离迁徙、植被的 转型和季风气候剧烈变化等等. 是什么因素触发了 $\sim 2.7 \mathrm{Ma}$ 北半球大冰期的发展、并引发了随后的冰期间冰期旋回?

在新生代, 地球处在一个逐渐变冷的过程 ${ }^{[26,27]}$. 在渐新世早期 34 Ma, 南极冰盖发育、地球从“温室 地球”进人“冰室地球”. 在晚中新世, 北半球高纬地 区冰筏沉积出现, 表明北半球高纬变冷. 最为引人注 目的是, 晚上新世 2.7 Ma北半球的冰盖急剧发展, 大冰期降临 ${ }^{[7,17]}$. 北半球大冰期发展的原因, 总体上 可分为构造活动和气候系统因素驱动两大类, 也可 能是两种因素综合作用的结果. 但是, 迄今还没有一 种解释可以获得广泛认同.

关于冰期 - 间冰期旋回的成因, 法国科学家 Joseph Adhemar在1842年就提出, 地球轨道变化引发 的地球接受太阳辐射量变化驱动的假说. 之后, 南斯 拉夫科学家Milankovitch在1920 1930年认为, 由于 天体之间的引力摄动, 地球绕太阳旋转轨道发生万 年时间尺度的周期性变化, 当黄赤交角较小、北半球 夏季位于远日点时, 北半球高纬地区接受的太阳辐 射量可能减少 20\%. 夏季太阳辐射减少、地表温度 降低, 使冬季积雪难以消融, 日积月累, 发育冰川. 由于冰川的高反照率, 更多的辐射能量被反射回太 空, 这种负反馈作用使地表更冷, 冰川生长更大, 地 球进人冰期气候. 反之, 进人间冰期气候. 影响高纬 地区太阳辐射量变化的主要因素是地球自转轴轨迹 的变化(岁差(precession), 有 23和 19 ka的周期)、地 球赤道面与黄道面的夹角(黄赤夹角, 有 $41 \mathrm{ka}$ 的周 期)和地球公转轨道偏心率(Eccentricity, 有 100和 
(a)

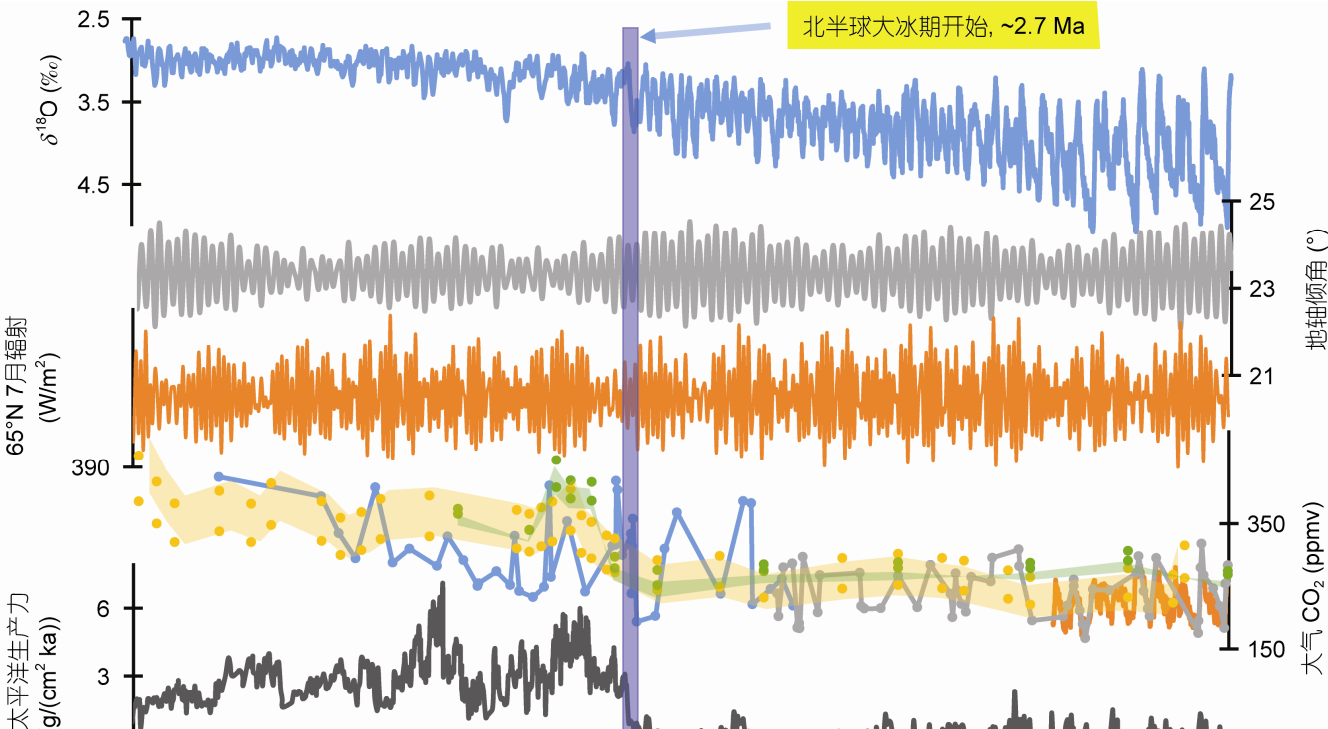

\section{○}

定

$0 \perp$
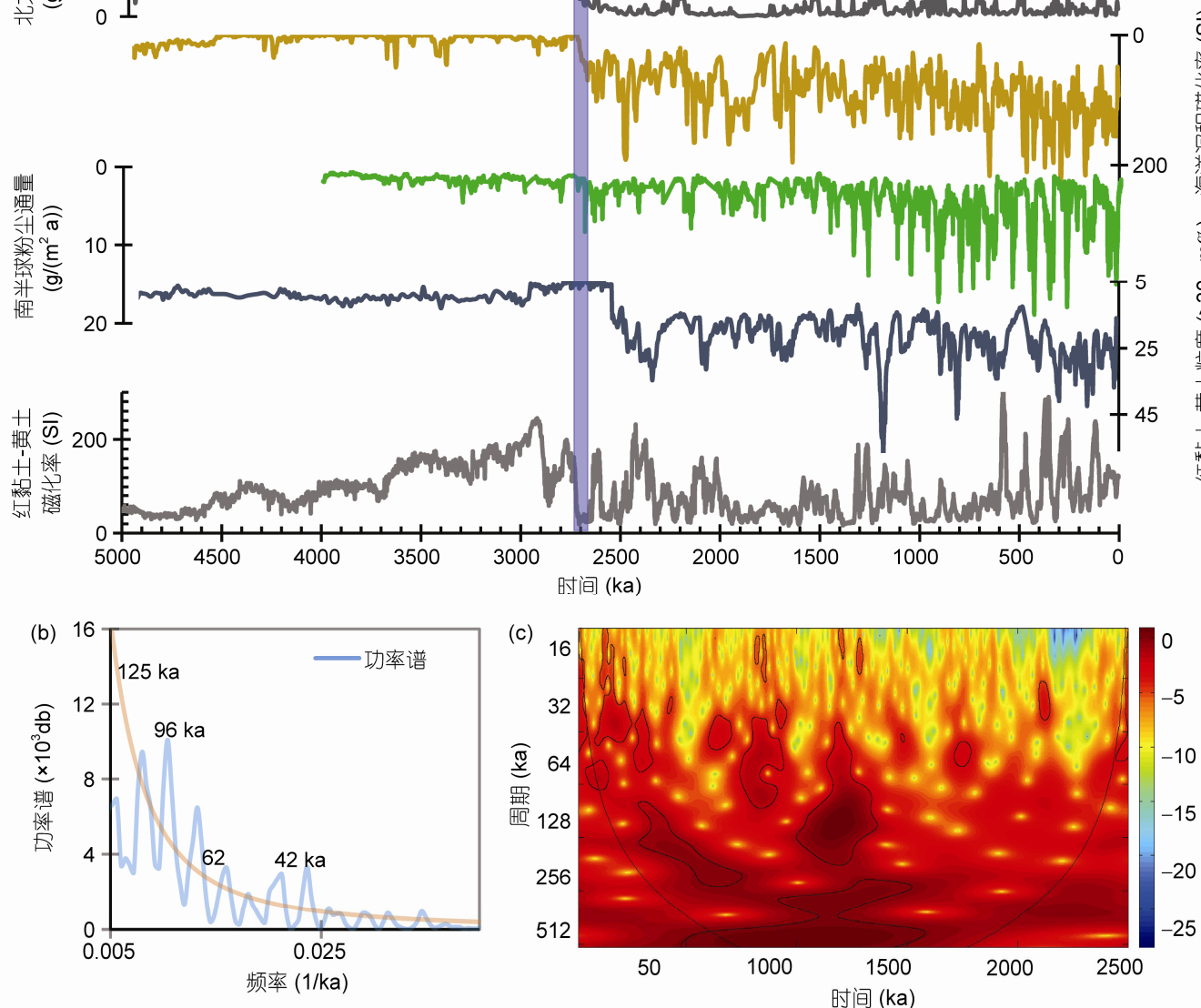

图 1 上新世以来冰期气候演化过程与陆地-海洋环境变化. (a) 最近 $5 \mathrm{Ma}$ 地球古气候变化 $\left(\text { 深海 } \delta^{18} \mathrm{O}\right)^{[13]}$ 及其与地球轨道参数(Obliquity)、太阳 辐射 $\left(65^{\circ} \mathrm{N} 7 \text { 月 }\right)^{[14]}$, 大气 $\mathrm{CO}_{2}{ }^{[15]}$ 、北太平洋海洋生产力和沉积物磁化率(指示物源变化 $)^{[5]}$ 、南半球粉尘量的变化 ${ }^{[16]}$ 以及中国红黏土-黄土磁化率 和粒度变化及其周期. (b) 功率谱(不等距时间序列)采用redfit3.5 软件, (c) 小波分析(三次样条函数内插值得到的等距时间序列)获得的黄土磁 化率最近 $2.5 \mathrm{Ma}$ 以来的周期演化特征

Figure 1 The ice age climate evolution and land-sea paleoenvironment change since Pliocene. (a) Paleoclimatic record of deep-sea sediment $\delta^{18} \mathrm{O}$ over the past $5 \mathrm{Ma}^{[13]}$, and the obliquity and insolation of $65^{\circ} \mathrm{N}^{[14]}$, the atmospheric $\mathrm{CO}_{2}^{[15]}$, drop in biogenic opal mass accumulation rates (MAR) at ODP Site 882 in the subarctic Northwest Pacific and ice-rafted detritus (IRD) input to the subarctic Northwest Pacific, as indicated by the increase in magnetic susceptibility ${ }^{[5]}$, the dust deposition rate in south Ocean ${ }^{[16]}$ and Chinese Red Clay-loess record, the magnetic susceptibility and grain size variations respectively. (b) The maximum entropy spectrum and (c) wavelet analyses of the loess record over the past $2.5 \mathrm{Ma}$, in which the time scale is built by unequally spaced array and cubic spline interpolation of independent age constraints 
$\sim 400 \mathrm{ka}$ 的周期). 计算表明, 具有决定意义的夏季 $65^{\circ} \mathrm{N}$ 地区, 随着偏心率的变化太阳辐射量只有 2 $\mathrm{W} / \mathrm{m}^{2}$ 的变化幅度, 这一量值是太阳常数 $1367 \mathrm{~W} / \mathrm{m}^{2}$ 的 $1 / 683$, 也比黄赤夹角 (约 $30 \mathrm{~W} / \mathrm{m}^{2}$ ) 和岁差 (约 60 $\mathrm{W} / \mathrm{m}^{2}$ ) 等影响的太阳辐射量低一个数量级, 因此, 偏 心率可能影响冰期气候周期但很难起到决定性作用. Hays等人 ${ }^{[28]}$ 对南印度洋深海 500 ka沉积记录的详细 研究, 发现地球气候变化存在着显著的轨道周期, 从 频率统计方面证实了 Milankovitch的预测. 其后, 大 量的研究支持他们的结论. 但是, 随着研究的深人, 冰期气候的轨道驱动理论还存在着不能回避的难 题 ${ }^{[22,29]}$ : 由于岁差的影响, 南北半球夏季的太阳辐射 变化是反相位的, 也就是说, 在北半球夏季接受太阳 辐射量减少而进人冰期时, 南半球则应该是温暖的 间冰期, 但是, 地质记录表明南北半球岁差周期同步 变化. 一方面, $\mathrm{CO}_{2}$ 的全球一致性表明其在两半球气 候同步变化中必然起到重要作用, 但是 $\mathrm{CO}_{2}$ 最大的源 和汇被认为是在南大洋, 南大洋通过 “生物㬌” 作用 调节 $\mathrm{CO}_{2}$ 的输人和输出 ${ }^{[2]}$, 而南大洋位于南半球, 北 半球的气候信号如何传输到南大洋并调节生物原效 应? 这一过程还有待模型的检验. 另一方面, 新的高 分辨率南极冰芯研究表明, 在 D-O旋回事件中, 北半 球冷暖事件要超前于南半球 200 年左右, 温盐传送带 在其中扮演着重要角色 ${ }^{[30]}$. 正如前文所述, 偏心率 周期调控的太阳辐射量变化很小, 但是, 100 ka的周 期却很强, 尤其是在 1.2 Ma以来明显超出了黄赤夹 角和岁差的周期, 其原因何在? 也有研究表明, 晚更 新世以来的 $100 \mathrm{ka}$ 周期可能是时间标尺建立过程中 人为带人的, 这个周期或接近 $80 \mathrm{ka}$, 或接近 120 $\mathrm{ka}^{[10,31]}$. 无论 $100 \mathrm{ka}$ 周期是对黄赤交角和岁差的综合 响应 ${ }^{[32]}$, 还是对偏心率的响应 ${ }^{[33]}$, 都需要有合理的 物理机制解释. 一般认为是全球变冷背景下的系统 内部反馈作用发生变化造成的, 尤其是冰反馈作用, 一方面当冰盖累积到一定程度, 产生 “过剩 冰”(excess ice), 由于均衡效应, 冰盖高程下降, 地表 面温度升高, 在冰消期快速崩塌 ${ }^{[34]}$; 另一方面, 大量 海冰的出现, 增大了地表反射, 使得暖期冰盖的消融 量远不及积雪的最大累积速率, 也可能是 $100 \mathrm{ka}$ 周期 产生的原因 ${ }^{[35]}$.

\section{2 第四纪冰期的成因}

晚新生代地球气候是阶段性变冷的, 尤其是在 $\sim 10 \mathrm{Ma}$ 北半球高纬冰筏沉积的发现和 2.7 Ma大冰期 的来临, 是引人注目的事件 ${ }^{[27]}$. 著名的高原隆升-风 化吸收 $\mathrm{CO}_{2}$-全球降温的假说 ${ }^{[36]}$, 提供了一个解释地 球变冷的思路. 但是, 新的大量证据表明, 一方面高 原主要隆升的时间与大冰期来临的时间不匹配; 另 外一方面, 按现有的模式计算高原隆升的硅酸盐风 化能在很短的时间内 (数十万年)消耗完大气全部的 $\mathrm{CO}_{2}$, 应该还有其他的作用在进行着 $\mathrm{CO}_{2}$ 的补偿 ${ }^{[37]}$. 因此, 这一假说解释大冰期的成因受到质疑 ${ }^{1)}$.

关于 2.7 Ma大冰期的成因, 主要的假说有: (1) 地球轨道参数配置使得北半球高纬接受太阳辐射量 达到极小值, 进而引发了第四纪大冰期 ${ }^{[1]} ;$ (2) 由于 巴拿马海峡关闭等, 促使向北太平洋的热盐环流加 强, 带来更多的热量到高纬度地区, 使得北太平洋高 纬地区水汽蒸散加强、降雪增多, 冰雪的反馈作用使 得冰盖/冰川大发展 ${ }^{[5]}$; (3) 冰川的负向自调节反馈作 用 ${ }^{[21]}$; (4) 亚轨道时间尺度气候变化和轨道时间尺度 驱动相互作用的结果 ${ }^{[38]}$; (5) 最近, 一种观点认为, 印度尼西亚及其周边地区的岛屿生长、陆地面积增 大, 改变了沃克环流, 增强了赤道太平洋部和东西部 的温度差, 出现像厄尔尼诺形式的大气-海洋环流形 式, 这种环流使得北美-加拿大地区的冰雪积累加强, 负反馈的作用促使冰盖增大; 同时, 赤道地区增长的 陆地加强了地表风化, 吸收了更多的大气 $\mathrm{CO}_{2}$, 使地 球更冷 ${ }^{[6]}$; (6) 我们正在执行的中美合作研究项目 (Dust stimulated drawdown of atmospheric $\mathrm{CO}_{2}$ as a trigger for Northern Hemisphere Glaciation), 拟通过 对晚上新世亚洲构造变形-中亚干旱化加强-输人大 洋粉尘增多-海洋铁肥效应增强-生物量增多-吸收更 多大气 $\mathrm{CO}_{2}$-地球变冷-冰盖增大假说的研究, 检验粉 尘排放和输人海洋粉尘增多在驱动全球变冷和大冰 期发展的作用.

从上述分析可见，有多种因素对 2.7 Ma的大冰 期发展有驱动作用, 但没有一种作用可以完美解释 大冰期的成因. 在新生代北半球高纬有很多次达到 了太阳辐射的极低值(图 1), 并且冰川的负反馈作用 会随时存在, 为何恰恰在 $2.7 \mathrm{Ma}$ 大冰期快速发展?

1) Molnar. Mantle dynamics and the rise and fall of mountain belts. Crafoord Symposium in Geoscience. Royal Swedish Academy of Sciences, 2014 
新证据表明, 巴拿马海峡关闭早于大冰期的来临, 因 而不是直接驱动因素. 关于厄尔尼诺大气-环流驱动 冰期的假说 ${ }^{[39]}$, 因为其难以量化也受到质疑. 虽然 粉尘的铁肥效应可能起到碳汇作用, 使大气 $\mathrm{CO}_{2}$ 含量 降低、地球变冷、北半球高纬地区冰盖增长, 但是, 冰 期的来临也可能使亚洲中部变干、粉尘释放量增多、 铁肥效应增强, 吸收更多的大气 $\mathrm{CO}_{2}$ 到海洋, 使得地 球更冷 ${ }^{[18]}$. 由于定年精度的限制, 现在还难以分辨 出粉尘增多和全球变冷谁先谁后, 因而, 成为新的 “鸡和蛋”的问题.

在 2.7 Ma北半球大冰期环境降临之后, 发生在 距今 1.0和 0.5 Ma的“中更新世革命 (MPT)”和“中布 容事件 (MBE)”, 也成为第四纪冰期气候最受关注的 问题之一 ${ }^{[9,40]}$. 在MPT和MBE前后, 冰期气候分别表 现为从 41 ka为主的周期转变为 $100 \mathrm{ka}$ 为主的周期、 冰期-间冰期旋回幅度增大、间冰期大气 $\mathrm{CO}_{2}$ 含量高于 以前和 400 ka周期不显著等特征. 关于MPT和MBE 发生的原因, 有全球的温度降低到一个阈值点引起 的冰期气候反馈循环 ${ }^{[41]}$ 、东南极冰盖的不稳定涨落、 海面变化联合驱动 ${ }^{[24]}$ 、北美高纬地区新出露岩石加 剧风化消耗 $\mathrm{CO}_{2}$ 降温驱动 ${ }^{[40]}$ 以及地球轨道作用下的 太阳辐射综合效应的结果 ${ }^{[9,42]}$ 等观点. 我们认为, 这 些气候周期转型时间发生在全球 ${ }^{[24]}$ 和区域 ${ }^{[23]}$ 的气候 记录中, 是气候系统(包括大气、海洋、陆地和冰冻 圈等)变化综合作用的结果, 其中, 区域太阳辐射和 大气 $\mathrm{CO}_{2}$ 变化可能起到了关键调节作用.

\section{3 第四纪冰期-间冰期旋回的驱动机制}

在地球接受太阳辐射量周期变化的背景下, 有 两个因素在驱动冰期-间冰期旋回中起关键的作用: 大洋环流和大气 $\mathrm{CO}_{2}$ 浓度. 研究表明, 大洋环流, 比 如大西洋经向反转流 (AMOC) 和全球温盐环流传送 带(thermohaline current) 在冰期终止运行, 明显地调 节着地球气候 ${ }^{[3,43]}$. 另外, 大气 $\mathrm{CO}_{2}$ 含量的周期变化, 其变化值在80 100 ppm(1 ppm=1 $\mu \mathrm{g} / \mathrm{g}$, 余同)之间 ${ }^{[2,20]}$, 可能控制着冰期-间冰期旋回变化. 大洋环流和大气 $\mathrm{CO}_{2}$ 含量变化、或者二者的共同作用, 放大了太阳辐 射量变化的影响, 引发了全球冰期-间冰期气候旋回.

一种观点认为 ${ }^{[3,25]}$, 在间冰期, 向北流的北大西 洋暖流, 具有盐度大和密度高的特点. 在高纬海区, 密度大的海水下沉, 形成北大西洋深层水(NADW), 由于补偿作用, 其向南流动并在南大洋与深层水混
合并进人太平洋, 继而北上, 在太平洋高纬地区折返 向南, 形成全球闭合的大洋传送带, 并传输热量. 由 NADW激发的全球大洋密度流-补偿流, 起到重要的 热量调节作用，其在间冰期启动、在冰期关闭，可以 认为, 驱动着冰期-间冰期气候旋回. 另一种观点认 为 ${ }^{[4,44]}$, 低纬地区的El Niño-La Niña大气-海洋形式变 换, 可能是冰期气候旋回的重要驱动机制. 在上新世 早期, 太平洋东部和西部海表的温差小, 表现为 $\mathrm{El}$ Niño形式, 影响着哈德莱环流和沃克环流, 使得北半 球高纬尤其是北美地区温度升高，气候温暖、形成间 冰期气候. 在La Niña形式下, 太平洋东西温差大, 赤 道海洋地区的温度降低, 通过大气环流调节, 使北半 球高纬地区的温度降低、冰川发育生长, 加上其反馈 作用, 形成冰期气候.

南北半球同时经历冰期-间冰期气候, 大气 $\mathrm{CO}_{2}$ 含量变化被认为是重要的驱动因素. 海洋和冰芯沉 积记录揭示, 在第四纪, 全球冰期-间冰期的温度变 化与大气 $\mathrm{CO}_{2}$ 含量同步 ${ }^{[15,20]}$. 古气候模拟也支持这个 结论 ${ }^{[45]}$. 最近的研究发现, 南大洋可能在全球大气 $\mathrm{CO}_{2}$ 循环中起到重要的调节作用. 在冰期, 南大洋的 海洋表层生物生产力提高, 生物泵(biological bump) 作用加强, 把更多的有机质传输到海表混合层(深度 100 200 m) 以下, 同时, 海洋表层会吸收更多的 $\mathrm{CO}_{2}$, 合成更多的有机质向深海输送. 传输到中层水和深 海的有机质被降解, 产生 $\mathrm{CO}_{2}$, 形成酸性的海水, 这 样会溶解更多的钙质物质(包括生物壳等), 增强了海 水的储碳功能. 在间冰期, 这个循环机制减弱或者停 滞 ${ }^{[2]}$, 更多的 $\mathrm{CO}_{2}$ 被释放到大气中, 使得大气 $\mathrm{CO}_{2}$ 含 量增多. 由于海洋可能是最大的碳库 (相对于陆地的 土壤、植被等), 其应该是大气 $\mathrm{CO}_{2}$ 的主要调节器, 尤 其是大洋生物碳泵运行过程的变化, 会明显改变大 气 $\mathrm{CO}_{2}$ 含量. 这个碳循环机制与我们的直觉有差异, 但是, 由于南大洋巨大的面积和热容量, 可能对冰期间冰期大气 $\mathrm{CO}_{2}$ 含量有 $40 \mathrm{ppmv}$ 的贡献, 因而, 在冰 期-间冰期气候变化中发挥着重要作用. 最近的研究 还发现，在冰期-间冰期旋回中，陆地向大洋输送的 粉尘发生着很大变化, 在冰期, 粉尘输人增多, 提供 了更多的营养物质, 生物量可能增加, 增加了海洋碳 汇 ${ }^{[16]}$. 但是, 其中的定量研究还不够.

高精度的石笋 ${ }^{230} \mathrm{Th}$ 定年技术 ${ }^{[46,47]}$, 为认识亚洲 季风气候变化和冰期旋-间冰期旋回, 提供了高质量 的记录. Cheng等人 ${ }^{[47]}$ 的研究表明, 如果中国石笋的 
氧同位素变化指示季风气候变化、而季风气候变化与 冰量变化相关, 那么, 石笋记录揭示的过去 4 个冰期 的快速退缩 (相对于冰盖的生长), 证实了冰期发展 慢、退缩快的特征. 并且, 他们认为, 升高的太阳辐 射量使得高纬地区的冰盖/冰川融化, 融化的冰川/冰 盖(可能减少了对太阳辐射的反馈)调节大洋环流和 大气 $\mathrm{CO}_{2}$ 含量, 加速了这一过程. 这个结论支持了太 阳辐射对低纬季风、高纬冰川/冰盖发展直接驱动的 认识 ${ }^{[48,49]}$, 而不支持冰期气候发展、亚洲季风气候演 化对冰量变化滞后的结论 ${ }^{[50]}$. 但是, 正如许多洞穴 记录解释受到的争议一样 ${ }^{[51]}$, 在石笋年代测试中、尤 其是较老的石笋沉积, 可能受到其他因素的影响, 使 得定年有偏离. 并且, 石笋稳定氧同位素并不是全球 冰期温度/冰量的直接替代性指标, 它们是区域(比如 季风强度或者水汽源区等)的甚至是局域的环境替代 性指标. 因此, 在讨论全球冰期气候变化过程中, 区 域的石笋记录并不是全球冰量/全球温度的直接指示, 最多是间接性的. 关于全球变化和低纬季风变化的 关系, 还需要寻找更好的替代性指标、作更深人的研 究.

古气候模拟为我们深人认识冰期气候起源, 提 供了很多证据. 模拟结果显示 ${ }^{[45,52]}$, 冰期气候旋回变 化与太阳辐射量变化密切相关, 大气 $\mathrm{CO}_{2}$ 、大洋环流 和下垫面的变化放大或者调制了太阳辐射驱动影响,
并且, 大气 $\mathrm{CO}_{2}$ 变化可能在全球温度和冰期-间冰期 旋回中起到关键作用; 构造活动在长时间尺度可能 控制着区域古气候的变化 ${ }^{[53]}$. 详细的评述可参考文 献 $[54,55]$. 但是, 我们也应看到, 古气候模拟还难以 重现南北半球的 see-saw现象, 模拟结果与数据记录 之间还存在矛盾 ${ }^{[52,56]}$. 这些问题都说明, 我们在认识 冰期气候的变化规律和机制方面, 数值模拟技术也 需改进.

\section{3 小结}

高纬地区太阳辐射量低值与大气 $\mathrm{CO}_{2}$ 含量、海陆 分布、大洋环流以及地表岩石风化强度、植被分布的 配置, 触发了第四纪冰期和“中更新世革命”. 地球轨 道参数影响的太阳辐射量周期变化, 可能是第四纪 冰期-间冰期气候旋回的根本驱动因素. 41和 23 ka 周期是在海洋、大气和地表调节作用下地球气候对轨 道参数变化的直接响应 ${ }^{[57]}$; 而 400和 100 ka周期可 能有更复杂的反馈机制 ${ }^{[21,22]}$, 甚至是气候系统内一 种自振荡现象 ${ }^{[10,58]}$. 因此, 冰期气候是多种因素综合 作用的结果, 太阳辐射量和大气 $\mathrm{CO}_{2}$ 浓度起关键作 用. 当然, 这些认识是否正确, 还需要进一步的研 究. 在将来, 获得高精度、定量化的古气候记录、提 高古气候模式的分辨率，可能是理解冰期气候成因 的前提.

\section{参考文献}

1 Maslin M A, Li X S, Loutre M F, et al. The contribution of orbital forcing to the progressive intensification of Northern Hemisphere glaciation. Quat Sci Rev, 1998, 17: 411-426

2 Sigman D M, Hain M P, Haug G H. The polar ocean and glacial cycles in atmospheric $\mathrm{CO}_{2}$ concentration. Nature, 2010, 466: 47-55

3 Broecker W, Denton G. What drives glacial cycles? Sci Am, 1990, 262: 42-50

4 Fedorov A V, Brierley C M, Lawrence K T, et al. Patterns and mechanisms of early Pliocene warmth. Nature, 2013, 496: 43-49

5 Haug G H, Ganopolski A, Sigman D M, et al. North Pacific seasonality and the glaciation of North America 2.7 million years ago. Nature, 2005, 433: 821-825

6 Molnar P, Cronin T W. Growth of the Maritime Continent and its possible contribution to recurring Ice Ages. Paleoceanography, 2015, 30: 196-225

7 Raymo M E. The initiation of Northern Hemisphere glaciation. Annu Rev Earth Planet Sci, 1994, 22: 353-383

8 Ruddiman W F, Raymo M, McIntyre A. Matuyama 41000-year cycles: North Atlantic Ocean and northern hemisphere ice sheets. Earth Planet Sci Lett, 1986, 80: 117-129

9 Yin Q. Insolation-induced mid-Brunhes transition in Southern Ocean ventilation and deep-ocean temperature. Nature, 2013, 494: 222-225

10 Maslin M A, Brierley C M. The role of orbital forcing in the Early Middle Pleistocene Transition. Quat Int, 2015, 389: 47-55

11 Emiliani C. Pleistocene temperatures. J Geol, 1955, 63: 538-578 
12 Shackleton N J, Opdyke N D. Oxygen isotope and palaeomagnetic stratigraphy of Equatorial Pacific core V28-238: Oxygen isotope temperatures and ice volumes on a $10^{5}$ year and $10^{6}$ year scale. Quat Res, 1973, 3: 39-55

13 Lisiecki L E, Raymo M E. A Pliocene-Pleistocene stack of 57 globally distributed benthic $\delta^{18} \mathrm{O}$ records. Paleoceanography, 2005, 20: PA1003

14 Berger A, Loutre M F. Insolation values for the climate of the last 10 million years. Quat Sci Rev, 1991, 10: 297-317

15 Bartoli G, Hönisch B, Zeebe R E. Atmospheric $\mathrm{CO}_{2}$ decline during the Pliocene intensification of Northern Hemisphere glaciations. Paleoceanography, 2011, 26: PA4213

16 Martínez-Garcia A, Rosell-Melé A, Jaccard S L, et al. Southern Ocean dust-climate coupling over the past four million years. Nature, 2011, 476: 312-315

17 Shackleton N J, Backman J, Zimmerman H, et al. Oxygen isotope calibration of the onset of ice-rafting and history of glaciation in the North Atlantic region. Nature, 1984, 307: 620-623

18 Lu H Y, Wang X Y, Li L P. Aeolian sediment evidence that global cooling has driven late Cenozoic stepwise aridification in central Asia. In: Clift P D, Tada R, Zheng H, eds. Monsoon Evolution and Tectonics-Climate Linkage in Asia. London: Geological Society, Special Publications, 2010, 342: 29-44

19 Lu H Y, Guo Z T. Evolution of the monsoon and dry climate in East Asia during late Cenozoic: A review. Sci China Earth Sci, 2014, 57: 70-79

20 Jouzel J, Masson-Delmotte V, Cattani O, et al. Orbital and millennial Antarctic climate variability over the past 800000 years. Science, 2007, 317: 793-796

21 Imbrie J, Berger A, Boyle E A, et al. On the structure and origin of major glaciation cycles 2. The 100000-year cycle. Paleoceanography, 1993, 8: 699-735

22 Wang P X, Li Q Y, Tian J, et al. Long-term cycles in the carbon reservoir of the Quaternary ocean: A perspective from the South China Sea. Nat Sci Rev, 2014, 1: 119-143

23 Lu H Y, Zhang F Q, Liu X D, et al. Periodicities of palaeoclimatic variations recorded by loess-palaeosol sequences in China. Quat Sci Rev, 2004, 23: 1891-1900

24 Raymo M E, Lisiecki L E, Nisancioglu K H. Plio-Pleistocene ice volume, Antarctic climate, and the global $\delta^{18} \mathrm{O}$ record. Science, 2006, 313: 492-495

25 Ravelo A C, Andreasen D H, Lyle M, et al. Regional climate shifts caused by gradual global cooling in the Pliocene epoch. Nature, 2004, 429: $263-267$

26 Zachos J C, Dickens G R, Zeebe R E. An early Cenozoic perspective on greenhouse warming and carbon-cycle dynamics. Nature, 2008, 451: 279-283

27 Lu H Y. Driving force behind global cooling in the Cenozoic: An ongoing mystery. Sci Bull, 2015, 60: 2091-2095

28 Hays J D, Imbrie J, Shackleton N J. Variations in the Earth's orbit: Pacemaker of the ice ages. Science, 1976, 194: 1121-1132

29 Ganopolski A, Winkelmann R, Schellnhuber H J. Critical insolation- $\mathrm{CO}_{2}$ relation for diagnosing past and future glacial inception. Nature, 2016, 529: 200-203

30 WAIS Divide Project Members. Precise interpolar phasing of abrupt climate change during the last ice age. Nature, 2015, 520: 661-665

31 Huybers P, Wunsch C. Obliquity pacing of the late Pleistocene glacial terminations. Nature, 2005, 434: 491-494

32 Huybers P. Combined obliquity and precession pacing of late Pleistocene deglaciations. Nature, 2011, 480: 229-232

33 Lisiecki L E. Links between eccentricity forcing and the 100000-year glacial cycle. Nat Geosci, 2010, 3: 349-352

34 Abe-Ouchi A, Saito F, Kawamura K, et al. Insolation-driven 100000-year glacial cycles and hysteresis of ice-sheet volume. Nature, 2013, 500: 190-193

35 Tziperman E, Gildor H. On the mid-Pleistocene transition to $100-\mathrm{kyr}$ glacial cycles and the asymmetry between glaciation and deglaciation times. Paleoceanography, 2003, 18: 1-1-1-8

36 Raymo M E, Ruddiman W F. Tectonic forcing of late Cenozoic climate. Nature, 1992, 359: 117-122

37 Torres M A, West A J, Li G. Sulphide oxidation and carbonate dissolution as a source of $\mathrm{CO}_{2}$ over geological timescales. Nature, 2014, 507: 346-349

38 Willis K J, Kleczkowski A, Briggs K M, et al. The role of sub-Milankovitch climatic forcing in the initiation of the Northern Hemisphere glaciation. Science, 1999, 285: 568-571

39 Zhang Y G, Pagani M, Liu Z. A 12-million-year temperature history of the tropical Pacific Ocean. Science, 2014, 344: 84-87

40 Clark P U, Archer D, Pollard D, et al. The Middle Pleistocene transition: Characteristics, mechanisms, and implications for long-term changes in atmospheric $p \mathrm{CO}_{2}$. Quat Sci Rev, 2006, 25: 3150-3184

41 Paillard D. The timing of Pleistocene glaciations from a simple multiple-state climate model. Nature, 1998, 391: 378-381

42 Huybers P. Early Pleistocene glacial cycles and the integrated summer insolation forcing. Science, 2006, 313: 508-511 
43 Chen T Y, Robinson L F, Burke A, et al. Synchronous centennial abrupt events in the ocean and atmosphere during the last deglaciation. Science, 2015, 349: 1537-1541

44 Huybers P, Molnar P. Tropical cooling and the onset of North American glaciation. Clim Past, 2007, 3: 549-557

45 Liu Z, Otto-Bliesner B L, He F, et al. Transient simulation of last deglaciation with a new mechanism for Bølling-Allerød warming. Science, 2009, 325: 310-314

46 Wang Y J, Cheng H, Edwards R L, et al. Millennial- and orbital-scale changes in the East Asian monsoon over the past 224000 years. Nature, 2008, 451: 1090-1093

47 Cheng H, Edwards R L, Broecker W S, et al. Ice age terminations. Science, 2009, 326: 248-252

48 Kutzbach J E. Monsoon climate of the early Holocene: Climate experiment with the Earth's orbital parameters for 9000 years ago. Science, 1981, 214: 59-61

49 Kutzbach J E, Liu X D, Liu Z Y, et al. Simulation of the evolutionary response of global summer monsoons to orbital forcing over the past 280000 years. Clim Dyn, 2008, 30: 567-579

50 Clemens S C, Prell W L, Sun Y. Orbital-scale timing and mechanisms driving Late Pleistocene Indo-Asian summer monsoons: Reinterpreting cave speleothem $\delta^{18} \mathrm{O}$. Paleoceanography, 2010, 25: PA4207

51 Moseley G E, Edwards R L, Wendt K A, et al. Reconciliation of the Devils Hole climate record with orbital forcing. Science, 2016, 351: $165-168$

52 Liu Z, Zhu J, Rosenthal Y, et al. The Holocene temperature conundrum. Proc Natl Acad Sci USA, 2014, 111: E3501-E3505

53 Zhang Z S, Ramstein G, Schuster M, et al. Aridification of the Sahara desert caused by Tethys Sea shrinkage during the Late Miocene. Nature, 2014, 513: 401-404

54 Liu X D, Shi Z G. Effect of precession on the Asian summer monsoon evolution: A systematic review. Chin Sci Bull, 2009, 54: 3720-3730 [刘晓东, 石正国. 岁差对亚洲夏季风气候变化影响研究进展. 科学通报, 2009, 54: 3097-3107]

55 Liu X D, Guo Q C, Guo Z T, et al. Where were the monsoon regions and arid zones in Asia prior to the Tibetan Plateau uplift? Nat Sci Rev, 2015, 2: 403-416

56 Guo Z T, Yang X D, Chen F H, et al. Climate changes in China since the Last Glacial Maximum and Holocene human adaptation (in Chinese). Chin Sci Bull, 2014, 59: 2937-2939 [郭正堂, 羊向东, 陈发虎, 等. 末次冰盛期以来我国气候环境变化及人类适应. 科学 通报, 2014, 59: 2937-2939]

57 Imbrie J, Hays J D, Martinson D G, et al. The orbital theory of Pleistocene climate: Support from a revised chronology of the marine $\delta^{18} \mathrm{O}$ record. In: Berger A, ed. Milankovitch and Climate. New York: Springer, 1984, 1: 269-305

58 Oerlemans J. Glacial cycles and ice-sheet modelling. Clim Change, 1982, 4: 353-374

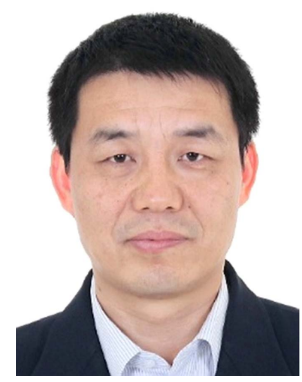

\section{鹿化显}

1968 年 4 月出生于陕西西安. 理学博士、南京大学教授, 中国科学院青藏高 原地球科学卓越创新中心特聘客座研究员。从事地球表层环境演化和自然地 理学的教学与研究工作, 曾深入青藏高原、黄土高原、沙漠腹地与罗布泊和 印度洋-阿拉伯海等地进行过 60 余次的科学考察工作, 发表论文 100 余篇, 被引用 5000 余次(包括被 SCI 期刊引用 3000 余次). 任国务院学科评议组成 员、《科学通报》等多个国内外学术期刊编委. 曾入选教育部长江学者特聘教 授、科技部中青年科技领军人才等计划. 


\title{
What causes the ice ages in the late Pliocene and Pleistocene?
}

\author{
$\mathrm{LU}_{\mathrm{HuaYu}}{ }^{1,2} \&$ WANG Yao ${ }^{1}$ \\ ${ }^{1}$ School of Geography and Ocean Science, Nanjing University, Nanjing 210023, China; \\ ${ }^{2}$ CAS Center for Excellence in Tibetan Plateau Earth Sciences, Beijing 100101, China
}

For more than a century, two families of ice age theories have been proposed: insolation based theories proposed by Adhémar, and atmospheric $\mathrm{CO}_{2}$ ones proposed by Tyndall. The major technique advance of deep-sea sediment drilling, as well as new interpretations of stable oxygen isotopic composition of the deep-sea fossil foraminifera, which is regarded as a proxy index of continental ice volume and sea water temperature, established the now well recognized glacial-interglacial variations in climate over the late Pliocene and Pleistocene, e.g. 3 Ma. A landmark progress came from Hays et al. (1976) who unambiguously demonstrated that the change in insolation induced by the Earth's axial tilt (obliquity), the wobble of this tilt (precession), and the degree of circularity of the Earth's orbit around the sun (eccentricity) brings on ice ages (glaciations) every hundred thousand years or so during the Pleistocene. Many subsequent observations, from the deep-sea to continental records, confirmed the co-variation between insolation and the alternation of glacial ice age phases, and warmer interglacial phases, at least in terms of frequency domains. However, these findings cannot explain the so called $\sim 100 \mathrm{ka}$ conundrum, where the size of 100 ka insolation forcing is relatively small yet the apparent ice sheet response is large, as well as the bi-polar symmetry in climate changes at precessional frequency of $\sim 23 \mathrm{ka}$, despite the fact that the precession cycle drives insolation changes in antiphase between the two hemispheres. As such, other factors may be considered in the driving of Northern Hemisphere Glaciation (NHG) global glacial-interglacial variations. Several hypotheses have been put forward, such as: (1) the gradual decreasing $\mathrm{CO}_{2}$ drove global cooling through to a threshold value where insolation changes may force the ice age cycles; (2) the effect of local insolation that modulated the East Antarctica Ice Sheet after the gradual $\mathrm{CO}_{2}$ decline that drove its growth to maximal extent; (3) the Southern Ocean "marine biological pump" changes forced by the ocean water stratification and current changes that modulated the atmospheric $\mathrm{CO}_{2}$ thus triggered ice ages; (4) the clearing of regolith under the North American ice sheets which modulate ice sheet thickness and extent changes which allow the ice sheets to grow further south and be influenced more by precessional cycles, as well as strengthened the fresh bedrock weathering and drawdown more atmospheric $\mathrm{CO}_{2}$; and (5) because ice mass balance depends on whether the temperature is above or below the freezing point, a physically more relevant parameter to measure insolation forcing should be the insolation integrated over a given threshold that allows for ice melting, and thus triggering the glaciations. Unfortunately, we cannot determine which one is right or several of them acting together so far. The most distinct features of the ice age climate are both the onset of the NHG at $\sim 2.7 \mathrm{Ma}$ and the transition of $\sim 41 \mathrm{ka}$ based glacial-interglacial cycles to cycles of a $\sim 100 \mathrm{ka}$ dominated frequency at $\sim 1.0 \mathrm{Ma}$, namely the Early Middle Pleistocene Transition. We suggest that, both insolation and $\mathrm{CO}_{2}$ changes together forced the climate of the ice ages: the stepwise cooling that occurred at $\sim 2.7 \mathrm{Ma}$ and $\sim 1.0 \mathrm{Ma}$ may be linked with gradual atmospheric $\mathrm{CO}_{2}$ reduction, during which the atmospheric $\mathrm{CO}_{2}$ levels fell to a threshold value that triggered high-latitude (both poles) ice expansion. Under a new cooling state since $\sim 2.7 \mathrm{Ma}$, the dominant climatic cycle at $\sim 41$ ka was forced by obliquity (orbital tilt), while the $\sim 23$ ka precession cycle was cancelled by opposing effects at both poles. On the other hand, we propose that the $\sim 100 \mathrm{ka}$ cycles that became dominant following approximately $1 \mathrm{Ma}$ were forced by a $\mathrm{CO}_{2}$ based "marine biological pump" change in the Southern Ocean, or is related to stochastic behavior of the ice sheets. The $\sim 400 \mathrm{ka}$ eccentricity cycle, which is a stronger absolute influence on insolation is an outstanding rhythm in the late Cenozoic, yet is not as strong in climate records as the precessional and obliquity cycles during the late Pliocene and Pleistocene, and thus needs further examination. In summary, we suggest ice ages are caused by the integrated forcing of insolation, atmospheric $\mathrm{CO}_{2}$, ocean conveyer and ice sheet feedback etc., in which the insolation forcing is primary, a threshold value of the other facts was attained, the ice age happened. However, our hypothesis is very tentative, more investigation is still needed on what causes the ice ages.

ice ages, insolation, atmospheric carbon dioxide, ocean conveyer, orbital time scale 